\title{
ANALISIS PERSEPSI KONSUMEN TERHADAP KEPUTUSAN MEMBELI ULANG PRODUK KUOTA IM3 OOREDOO DI KOTA BANJARMASIN
}

\author{
Jamaluddin \\ Akademi Sekretaris dan Manajemen Indonesia (ASMI) Citra Nusantara \\ J1. Soetoyo S, No. 197 Banjarmasin \\ e-mail: jamal_btp@yahoo.com
}

\begin{abstract}
The study aims to determine the effect of consumer perception factors that can influence the decision to repurchase IM3 Ooredoo products to consumers in the city of Banjarmasin. The factors of consumer perception examined include Price, Service Quality, Location, Personal and Stimulus. The population of the study is all Banjarmasin city residents who use the IM3 Ooredoo Quota. Samples were taken with a non-probability sampling method with a sampling quota of 125 samples. By using a questionnaire with a Likert scale method. The statistical test method uses Multiple Linear Regression Analysis, with the hypothesis testing of the t statistical test and the F statistical test. The results of the analysis based on the use of all independent variables indicate that consumers' perceptions namely Price, Service Quality, Location, Personal and Stimulus together are able to influence Buying Decisions Repeat IM3 Ooredoo Quota Products in Banjarmasin City. While partially only stimulus variables are not able to show a significant relationship with the variable Repurchase Decision of IM3 Ooredoo Products in Banjarmasin City.
\end{abstract}

Keywords: Price, Service Quality, Location, Personal, Stimulus, Repurchase Decision

\begin{abstract}
Abstrak
Penelitian bertujuan untuk mengetahui pengaruh faktor - faktor persepsi konsumen yang mampu mempengaruhi keputusan membeli ulang produk IM3 Ooredoo pada konsumen di Kota Banjarmasin. Faktor-faktor persepsi konsumen yang diteliti antara lain faktor Harga, Kualitas Layanan, Lokasi, Pribadi dan Stimulus.. Populasi yang penelitian merupakan semua masyarakat kota Banjarmasin yang menggunakan Kuota IM3 Ooredoo. Sampel diambil dengan metode nonprobability sampling dengan kuota sampling sebanyak 125 sampel. Dengan menggunakan kuesioner dengan metode skala likert. Metode pengujian statistik menggunakan Analisis Regresi Linear Berganda, dengan pengujian hipotesis uji statistik t dan uji statistik F. Hasil analisis berdasarkan penggunaan semua variabel independen menunjukkan bahwa persepsi konsumen yaitu Harga, Kualitas Layanan, Lokasi, Pribadi dan Stimulus secara bersama-sama mampu mempengaruhi Keputusan Membeli Ulang Produk Kuota IM3 Ooredoo Di Kota Banjarmasin. Sedangkan secara partial hanya variabel stimulus yang tidak mampu menunjukan hubungan signifikann dengan variabel Keputusan Membeli Ulang Produk Kuota IM3 Ooredoo Di Kota Banjarmasin.
\end{abstract}

Kata Kunci : Harga, Kualitas Layanan, Lokasi, Pribadi, Stimulus, Keputusan Membeli Ulang 


\section{PENDAHULUAN}

Penggunaan handphone atau telepon genggam di Indonesia mulai popular di era tahun 90 an. Keberadaannya dinilai mampu menggantikan fungsi telepon kabel yang biasanya hanya bisa ada di rumah atau di perkantoran saat pemakainya berada di luar area rumah atau kantor. Telepon genggam dinilai lebih praktis dan efisien dalam penggunaannya. hal ini disebabkan oleh fungsi telepon genggam tidak hanya mampu membuat pemiliknya berkomunikasi secara lisan dengan orang yang dituju, namun juga mampu menyampaikan pesan dalam bentuk tulisan.

Dalam perkembangannya di abad 21 saat ini, telepon genggam memiliki berbagai perubahan baik dari sisi kegunaan, perangkat dan lain sebagainya yang dipengaruhi oleh perkembangan teknologi berkembang. Telepon genggam saat ini seolah merupakan kebutuhan utama bagi manusia tidak hanya dalam rangka menjalin komunikasi antar sesame, namun telepon genggam dapat dianalogikan sebagai mata dalam melihat dan memahami apa yang saat ini terjadi tanpa ada batasan jarak, waktu dan ruang. Kecanggihan fitur telepon genggam dan segala teknologi yang mengikutinya. Namun secanggih apapun yang dimiliki oleh perangkat telepon genggam tersebut, akan tidak ada gunanya tanpa didukung adanya jaringan operator seluler yang ditanamkan dalam perangkat tersebut.

Semakin berkembang teknologi telepon genggam yang terjadi, maka kebutuhan akan operator selular dengan fitur yang mendukung teknologi tersebut akan semakin meningkat. Seperti misalnya, diawal kemunculan telepon genggam operator telepon hanya menyediakan jaringan mempermudah komunikasi yang mampu mendukung komunikasi sesuai teknologi saat itu yaitu telepon dan berkirim pesan. Namun perkembangan muncul dengan kebutuhan jaringan yang lebih canggih untuk mendukung kebutuhan komunikasi masyarakat dalam bentuk video. Dan saat ini kebutuhan masyarakat akan jaringan operator selular lebih meningkat ke tahap berikutnya. Hal ini didasari atas lairnya industri 4.0 yaitu perubahan industry yang ditandai adanya teknologi internet yang semakin canggih.

Saat ini kebutuhan akan komunikasi baik kebutuhan akan telepon genggam yang sesuai kebutuhan pemilik berbanding lurus dengan jaringan yang ditawarkan oleh operator selular. Operator selular di Indonesia saat ini terdapat 5 (lima) perusahaan penyedia layanan ini yaitu: Telkomsel, Hutchison Tri, Smartfren, Indosat Ooredoo, dan XL Axiata.

Setiap operator selular tersebut berlomba-lomba dalam menawarkan berbagai kecanggihan jaringan baik dalam kaitannya untuk kecepatan upload, kecepatan download, pengalaman video, koneksi jaringan telepon, ketersediaan jaringan 4G, serta koneksi latensi. Hal ini diakibatkan kebutuhan penggunanya akan hal tersebut cukup banyak. Apalagi pengguna telepon genggam sangat membutuhkan operator selular dalam rangka memenuhi kebutuhan berselancar di internet dan fitur otomatisasi lainnya dalam mendukung kehidupan sehari-hari.

Indosat Ooredoo sebagai salah satu perusahaan yang bergerak di bidang penyedia jaringan atau operator selular dengan merek dagang IM3 Ooredoo. Saat ini Indosat Ooredoo mengklaim terdapat 56,7 juta pengguna internet dan jaringan selular merupakan konsumen Indosat Ooredoo di akhir semester pertama tahun 2019. Indosat Ooredo memang tidak dinobatkan menjadi salah satu operator selular terbaik yang dinobatkan pada Juli 2019 dalam Laporan Pengalaman Jaringan Selular oleh 
OpenSignal. Hal ini bisa terjadi mengingat indosat Ooredoo saat ini fokus pada perbaikan dan penambahan jaringan dan infrasturtur dalam upaya peningkatan pelayanan terhadap pelanggannya. Tentu saja dengan peningkatan pelayanan bagi konsumennya, akan menimbulkan efek peningkatan terhadap penjualan produk sekaligus peningkatan terhadap pendapatan yang diperoleh.

Saat ini penyedia jasa layanan jaringan internet atau yang dalam masyarakat dikenal sebagai penyedia layanan kouta jaringan dituntut untuk menambah omzet penjualan melalui repeat buying (pembelian ulang) oleh konsumennya. Hal ini sejalan dengan regulasi pemerintah yang menetapkan regulasi bahwa kartu SIM (Subscriber Identity Module) yang dimiliki penggunanya harus teregistrasi dengan data sesuai NIK (Nomor Induk Kependudukan) dan KK (Kartu Keluarga) yang bersangkutan. Sehingga bisa dipastikan jika penggunanya akan melakukan pembelian ulang isi kuota untuk provider yang sama, dengan syarat ekspektasi mereka dapat dipenuhi provider tersebut.

Di tengah persaingan penyedia jasa layanan jaringan internet tersebut, maka indosat harus memperhatikan apasaja yang bisa mempengaruhi keputusan pembelian ulang produk mereka, salah satunya adalah memperhatikan persepsi konsumennya. Karena dengan melakukan hal tersebut, diyakini bahwa perusahaan akan mampu pula mempertahankan konsumennya. Dengan menanamkan persepsi yang baik secara subjektif kepada konsumen saat konsumen mengkonsumsi produk atau jasa yang ditawarkan, maka konsumen akan berpeluang dalam melakukan pembelian ulang terhadap produk atau jasa itu kembali (Mussadad, 2011).

Banyak hal yang bisa menjadi pembentuk persepsi seorang konsumen. Putri (2016) menyatakan faktor-faktor seperti lingkungan fisik, kepuasan pelanggan, kualitas layanan, preferensi merek, kualitas produk, nilai yang dirasakan (perceived value), dan harga dapat mempengaruhi keputusan membeli ulang suatu produk. Walaupun hasil penelitiannya menemukan lagi ada faktor lain seperti lingkungan fisik yang dapat mempengaruhi keputusan membeli ulang tersebut.

Penelitian Melisa (2012) meneliti faktor yang mempengaruhi keputusan pembelian ulang melalui faktor bauran pemasaran yaitu persediaan barang, harga, lokasi, bauran komunikasi, desain dan tampilan toko. Dimana semua variabel tersebut berpengaruh secara signifikan terhadap keputusan pembelian ulang pada Mega Prima Swalayan.

Peneliti lainnya seperti Awi \& Chaipoopirutana (2014), Pupuani \& Sulistyawati (2013), serta Joseph, dkk (2012), setidaknya mengungkapkan foktorfaktor yang dapat mempengaruhi minat pembelian ulang antara lain lingkungan fisik, kepuasan pelanggan, kualitas layanan, preferensi merek, kualitas produk, nilai yang dirasakan (perceived value), dan harga.

Penelitian ini bertujuan untuk mengetahui pengaruh faktor - faktor persepsi konsumen yang mampu mempengaruhi keputusan membeli ulang produk IM3 Ooredoo pada konsumen di Kota Banjarmasin. Faktor-faktor persepsi konsumen yang diteliti antara lain faktor Harga, Kualitas Layanan, Lokasi, Pribadi dan Stimulus. Faktor Pribadi dan Stimulus dipakai sebagai bagian karakter konsumen yang juga diduga mampu mempengaruhi keputusan pembelian ulang.

\section{Kajian Pustaka}

Persepsi Konsumen

Menurut Schiffman dan Kanuk (2010) mendefinisikan persepsi sebagai sebuah 
sikap atau perilaku sesorang atau konsumen yang ditunjukan dalam mencari, membeli, menggunakan, mengevaluasi dan menghabiskan produk dan jasa yang mereka harapkan untuk mendapatkan kepuasan dalam memenuhi kebutuhan mereka. Menurut Kotler dan Amstrong (2008) persepsi adalah proses dimana kita memilih, mengatur, dan menerjemahkan,masukan informasi untuk menciptakan gambaran dunia yang berarti.

Hurriyati (2010) menyatakan bahwa: "Persepsi adalah proses yang dilalui orang dalam memilih, mengorganisasikan, dan menginterpretasikan informasi guna membentuk gambaran berarti mengenai dunia". Proses pengambilan keputusan yang dilakukan oleh konsumen utamanya merupakan perilaku konsumen. Konsumen yang memilih produk secara kritis dapat mengambil keputusannya dalam membeli produk secara tepat. Menurut Peter dan Olson (2010) perilaku konsumen melibatkan pemikiran dan perasaan yang mereka alami serta tindakan yang mereka lakukan dalam proses konsumsi.

\section{Faktor-faktor Yang Mempengaruhi Persepsi Konsumen}

Menurut Shiffman dan Kanuk (2008) persepsi akan sesuatu berasal dari interaksi antara dua jenis faktor: 1) Faktor stimulus, yaitu karakteristik secara fisik seperti ukuran, berat, warna atau bentuk; 2) Faktor individu yang termasuk proses di dalamnya bukan hanya pada panca indra akan tetapi juga pada proses pengalaman yang serupa dan dorongan utama serta harapan dari individu itu sendiri.

Menurut Robbins (2009), persepsi dapat dipengaruhi oleh karakter seseorang. Karakter tersebut dipengaruhi oleh:

1) Attitude yaitu dua individu yang sama, tetapi mengartikan sesuatu yang dilihat itu berbeda satu dengan lainnya.
2) Motivies yaitu kebutuhan yang tidak terpuaskan yang mendorong individu dan mungkin memiliki pengaruh yang kuat terhadap persepsi mereka.

3) Interest yaitu fokus dari perhatian kita sepertinya dipengaruhi oleh minat kita, karena minat seseorang berbeda satu dengan lainnya

4) Experiences yaitu fokus dari karakter individu yang berhubungan dengan pengalaman masa lalu seperti minat atau interest individu.

5) Expectations yaitu ekspektasi bisa mengubah persepsi individu dimana individu tersebut bisa melihat apa yang mereka harapkan dari apa yang terjadi sekarang

\section{Keputusan Pembelian}

Keputusan pembelian menurut Schiffman dan Kanuk (2008) adalah the selection of an option from two or alternative choice. Jadi, keputusan pembelian adalah suatu keputusan seseorang dimana dia memilih salah satu dari beberapa alternatif pilihan yang ada. Indikator dari Keputusan Pembelian adalah : (1) Pengenalan Masalah atau Kebutuhan (2) Pencarian Informasi (3) Evaluasi Alternatif (4) Keputusan Pembelian (5) Perilaku Pasca Pembelian

Menurut Tjiptono (2010), keputusan pembelian adalah sebuah proses dimana konsumen mengenal masalahnya, mencari informasi mengenai produk atau merek tertentudan mengevaluasi seberapa baik masing-masing alternativ tersebut dapat memecahkan masalahnya, yang kemudian mengarah kepada keputusan pembelian. Konsumen akan memilih suatu produk yang lebih dikenalnya (diketahuinya) dibandingkan dengan membeli suatu produk yang belum pernah dikenalnya sama sekali Huwaida (2017). 


\section{Faktor Yang Mempengaruhi Pembelian}

Adapun indikator yang mempengaruhi keputusan pembelian tersebut menurut Sweeney dan Soutar (2002) yaitu nilai emosional, nilai sosial, nilai kualitas dan nilai fungsional.

1) Nilai emosional

Utilitas yang berasal dari perasaan atau afektif atau emosi positif yang ditimbulkan dari mengkonsumsi produk.

Kalau konsumen mengalami perasaan positif (positive feeling) pada saat membeli atau menggunakan suatu merek, maka merek tersebut memberikan nilai emosional.

2) Nilai sosial

Nilai sosial merupakan nilai yang dianut oleh suatu konsumen, mengenai apa yang dianggap baik dan apa yang dianggap buruk oleh konsumen. Atributatribut dari nilai sosial tersebut meliputi kemampuan sebuah produk untuk menimbulkan rasa bangga kepada konsumen dan kemampuan sebuah produk untuk menimbulkan kesan yang baik kepada konsumen.

3) Nilai kualitas

Nilai kualitas merupakan nilai yang diperoleh dari persepsi pelanggan terhadap kualitas dan kinerja yang diharapkan atas produk atau jasa. Atribut-atribut dari nilai kualitas meliputi manfaat yang diperoleh konsumen setelah mengkonsumsi produk tersebut dan konsistensi pelayanan oleh karyawan perusahaan. Utilitas yang didapat dari produk karena reduksi biaya jangka pendek dan biaya jangka panjang.

4) Nilai fungsional

Adalah nilai yang diperoleh dari atribut produk yang memberikan kegunaan (utility) fungsional kepada konsumen nilai ini berkaitan langsung dengan fungsi yang diberikan oleh produk atau layanan kepada konsumen.

\section{Minat Membeli Ulang}

Peter/Olsen (2010) menyatakan minat beli ulang (repeat purchase) adalah kegiatan pembelian yang dilakukan lebih dari satu kali atau beberapa kali. Kepuasan yang diperoleh seorang konsumen, dapat mendorong ia melakukan pembelian ulan, menjadi loyal terhadap produk tersebut ataupun loyal terhadap toko tempat ia membeli barang tersebut sehingga konsumen dapat menceritakan hal-hal yang baik kepada orang lain.

Menurut Schiffman dan Kanuk (2008) perilaku beli ulang itu sangat berhubungan dengan adanya konsep dari brand loyalty, dimana kebanyakan perusahaan akan mendukung karena hal ini memiliki kontribusi yang besar untuk kestabilan yang baik di dalam marketplace.

Menurut Ike Kusdyah (2012) terjadinya minat beli ulang merupakan salah satu dari perilaku pembelian konsumen yang mana terdapat kesesuaian antara nilai dari barang atau jasa yang dapat menghasilkan minat konsumen untuk mengkonsumsinya lagi di kemudian hari. Keinginan konsumen untuk melakukan pembelian ulang suatu barang, sebagian besar didasarkan pada rasa percaya dan value yang berkaitan dengan penggunaan dari produk yang ditawarkan. Kotler (2007), menyatakan bahwa terdapat beberapa faktor utama yang mempengaruhi mint seseorang untuk melakukan pembelian ulang, psikologis, pribadi dan sosial. Masingmasing faktor tersebut terdiri dari unsurunsur yang lebih kecil yang membentuk satu kesatuan tentang bagaimana manusia berperilaku dalam kehidupan ekonominya

\section{Harga}

Tjiptono (2011) menatakan bahwa harga merupakan satuan moneter atau ukuran 
lainnya (termasuk barang dan jasa lainnya) yang ditukarkan agar memperoleh hak kepemilikan atau pengunaan suatu barang atau jasa. Pengertian ini sejalan dengan konsep pertukaran (exchange) dalam pemasaran. Faktor harga dinilai sangat penting yang diperhatikan oleh konsumen dalam membeli produk atau jasa. Jika konsumen merasa cocok dengan harga yang ditawarkan, maka mereka akan cenderung melakukan pembelian ulang untuk produk yang sama.

Dalam teori ekonomi disebutkan bahwa harga suatu barang atau jasa yang pasarnya kompetitif, maka tinggi rendahnya harga ditentukan oleh permintaan dan penawaran pasar. Menurut Kotler \& Amstorng (2008), indikator yang digunakan untuk mengukur harga antara lain: Keterjangkauan harga , Kesesuaian harga dengan kualitas produk , Daya saing harga, Kesesuaian harga dengan manfaat produksi danHarga mempengaruhi daya beli konsumen

\section{Kualitas Layanan}

Semua industri yang bergerak di bidang jasa harus memperhatikan segi layanan mereka (Nasution, 2014). Layanan yang merupakan salah satu syarat kesuksesan perusahaan jasa. Kualitas layanan dipandang sebagai salah satu komponen yang perlu diwujudkan oleh perusahaan karena memiliki pengaruh untuk mendatangkan konsumen baru dan dapat mengurangi kemungkinan pelanggan lama untuk berpindah ke perusahaan lain. Dengan semakin banyaknya pesaing maka akan semakin banyak pilihan bagi konsumen dalam menentukan pilihan terhadap jasa/produk yang akan dipakainya.

Menurut Lovelock \& Wright (2007) kualitas layanan adalah evaluasi kognitif jangka panjang pelanggan terhadap penyerahan jasa suatu perusahaan. Kualitas adalah totalitas fitur dan karakteristik produk atau jasa yang bergantung pada kemampuannya untuk memuaskan kebutuhan yang dinyatakan atau tersirat (Kotler \& Keller, 2009). Definisi kualitas layanan dapat diartikan sebagai upaya pemenuhan kebutuhan dan keinginan konsumen serta ketepatan penyampaiannya dalam mengimbangi harapan konsumen

Lokasi

Tjiptono (2002) menerangkan bahwa di dalam pemilihan lokasi diperlukan pertimbangan-pertimbangan yang cermat meliputi kemudahan (Akses) atau kemudahan untuk dijangkau dengan sarana trasnportasi umum, (Visibilitas) yang baik yaitu keberadaan lokasi yang dapat dilihat dengan jelas, lokasi berada pada lalu lintas (Traffic) atau berada pada daerah yang banyak orang berlalu lalang yang dapat memberikan peluang terjadinya impulse buying, lingkungan sekitar mendukung barang dan jasa yang di tawar kandang jauh dari lokasi pesaing

\section{Hipotesis yang dikembangkan}

H1= Faktor Harga, Berpengaruh Secara Partial Terhadap Keputusan Membeli Ulang Produk Kuota IM3 Ooredoo Di Kota Banjarmasin

H2 = Faktor Kualitas Layanan berpengaruh Terhadap Keputusan Membeli Ulang Produk Kuota IM3 Ooredoo Di Kota Banjarmasin

H3 = Faktor Lokasi berpengaruh Terhadap Keputusan Membeli Ulang Produk Kuota IM3 Ooredoo Di Kota Banjarmasin

H4 = Faktor Pribadi berpengaruh Terhadap Keputusan Membeli Ulang Produk Kuota IM3 Ooredoo Di Kota Banjarmasin

H5 = Faktor Stimulus berpengaruh Terhadap Keputusan Membeli Ulang Produk Kuota IM3 Ooredoo Di Kota Banjarmasin 
H6= Faktor Harga, Kualitas Layanan, Lokasi, Pribadi dan Stimulus Berpengaruh Secara Bersama-sama
(Simultan) Terhadap Keputusan Membeli Ulang Produk Kuota IM3 Ooredoo Di Kota Banjarmasin.

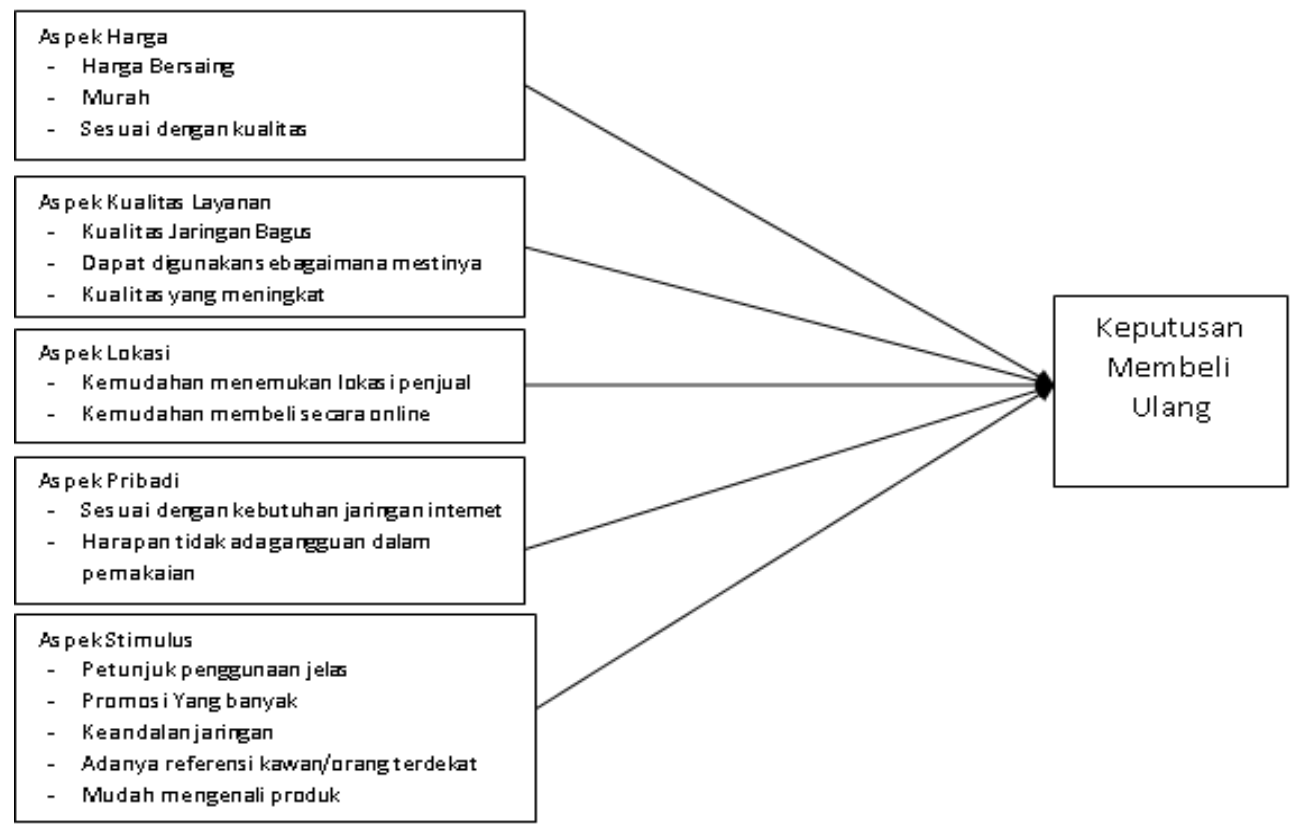

Gambar 1 : Kerangka Penelitian

Sumber: diolah Penulis, 2019

\section{METODE PENELITIAN}

\section{Jenis Penelitian}

Jenis penelitian yang dalam penelitian ini adalah penelitian deskriptif kuantitatif. Populasi penelitian ini adalah masyarakat Kota Banjarmasin. Sedangkan teknik pengambilan sampel yang digunakan dalam penelitian ini adalah non-probability sampling dengan kuota sampling. Sampel yang diambil sebanyak 125 sampel. Sampel ditentukan dengan kriteria yaitu mencakup masyarakat Kota Banjarmasin, dan merupakan pengguna IM3 Ooredoo yang sedang melakukan pengisian kuota IM3 Ooredoo pada saat kuesioner diserahkan.

\section{Metode Pengumpulan Data}

Metode yang digunakan penulis adalah dengan penyebaran kuisioner langsung kepengguna IM3 Ooredoo serta melalui studi pustaka. Pertanyaan kuesioner menggunakan metode Five Likert Scale. Dari kuesioner- kuesioner yang tersebar, terdapat 5 kuesioner yang tidak dapat digunakan sehingga terkumpul 125 kuisioner

\section{Analisis Data}

peneliti menggunakan 125 kuisioner tersebut untuk diproses lebih lanjut. Peneliti terlebih dahulu melakukan uji validitas dan uji reliabilitas terhadap kuesioner menggunakan program SPSS versi 21, kemudian pengujian dilakukan dengan uji asumsi klasik dan pengujian hipotesis menggunakan koefisien determinasi, uji $\mathrm{t}$ (partial) dan $\mathrm{Uji} F$ (simultan).

\section{Uji Validitas dan Reliabilitas}

Validitas menunjukkan sejauh mana alat ukur itu mengukur apa yang diukur. Tinggi rendahnya validitas instrumen menunjukkan sejauh mana data terkumpul tidak menyimpang dari gambaran tentang variabel yang diteliti. . Dalam penelitian ini 
ini digunakan asumsi bahwa nilai korelasi dengan metode Pearson product moment tinggi maka dikatakan valid. Kriteria validitas setiap item atau butir pertanyaan adalah jika $r$ (koefisien korelasi antara skor butir pertanyaan dengan total skor) $>0,30$ berarti item atau butir pertanyaan valid (Sujianto, 2009).
Instrumen dikatakan reliable apabila dipergunakan beberapa kali untuk mengukur obyek yang sama Pada pengujian ini uji reliabilitas dengan uji statistic Cronbach Alpha diketahui bahwa variabel dikatakan reliable jika memberikan nilai Cronbach Alpha lebih besar dari 0,70 (Nunnaly, dalam Ghozali, 2013). Hasil pengujian validitas dan reliabilitas disajikan dalam tabel berikut:

Tabel 2. Hasil Uji Validitas dan Reabilitas

\begin{tabular}{|l|c|c|c|}
\hline Pertanyaan & Pearson Product Moment & Cronbach's Alpha & Keterangan \\
\hline P1 & 0.41 & 0.80 & Valid dan Reliabel \\
\hline P2 & 0.34 & 0.80 & Valid dan Reliabel \\
\hline P3 & 0.42 & 0.80 & Valid dan Reliabel \\
\hline P4 & 0.45 & 0.80 & Valid dan Reliabel \\
\hline P5 & 0.48 & 0.80 & Valid dan Reliabel \\
\hline P6 & 0.53 & 0.79 & Valid dan Reliabel \\
\hline P7 & 0.47 & 0.80 & Valid dan Reliabel \\
\hline P8 & 0.41 & 0.80 & Valid dan Reliabel \\
\hline P9 & 20.41 & 0.80 & Valid dan Reliabel \\
\hline P10 & 0.50 & 0.79 & Valid dan Reliabel \\
\hline P11 & 0.59 & 0.79 & Valid dan Reliabel \\
\hline P12 & 0.49 & 0.80 & Valid dan Reliabel \\
\hline P13 & 0.46 & 0.79 & Valid dan Reliabel \\
\hline P14 & 0.45 & 0.80 & Valid dan Reliabel \\
\hline P15 & 0.45 & 0.80 & Valid dan Reliabel \\
\hline P16 & 0.71 & 0.78 & Valid dan Reliabel \\
\hline P17 & 0.71 & 0.77 & Valid dan Reliabel \\
\hline
\end{tabular}

Sumber: Data diolah, 2019

\section{HASIL DAN PEMBAHASAN}

Hasil

Tabel 2 menunjukkan deskripsi responden berdasarkan jenis kelamin, umur, pekerjaan, penghasilan, lama pakai produk indosat. Berdasarkan jenis kelamin, jumlah responden wanita sebanyak 59 orang (47\%) dan pria 66 orang (53\%). Dari penjabaran tersebut dapat diketahui bahwa mayoritas responden berjenis kelamin laki-laki.

Berdasarkan umur, responden dalam penelitian ini dibagi menjadi tig akelas yaitu umur $17-20$ tahun sebanyak 41 orang (33\%), umur 21 - 25 tahun sebanyak 33 orang (26\%), 26 - 30 tahun (24\%), dan yang berumur lebih dari 30 tahun sebanyak 21 orang $(17 \%)$. Dari data tersebut diketahui bahwa mayoritas responden berusia $17-20$ tahun.

Distribusi karakteristik berdasarkan pekerjaan di bagi menjadi 6 kelas. Jumlah responden yang berstatus pelajar /mahasiswa sebanyak 43 orang (34\%), swasta sebanyak 36 orang (29\%), PNS/ASN sebanyak 17 orang (14\%), wiraswasta sebanyak 10 orang $(8 \%)$, ibu rumah tangga sebanyak 15 orang (12\%), dab sisanya sebanyak 4 orang (3\%) di luar kategori tersebut. Dari pernyataan tersebut diketahui bahwa mayoritas responden berstatus sebagai pelajar/mahasiswa.

Berdasarkan penghasilan jumlah responden yan berpenghasilan kurang dari 1.500.000 sebanyak 53 orang $(42 \%)$, yang 
berpenghasilan $1.500 .001-2.500 .000$ sebanyak 24 orang (19\%), yang berpenghasilan $2.500 .001-3.500 .000$ sebanyak 27 orang (22\%), dan yang berpenghasilan di atas 3.500.000 sebanyak 21 orang $(17 \%)$. Dari pernyataan tersebut diketahui bahwa mayoritas responden berpenghasilan kurang dari 1.500.000.
Berdasarkan lama menggunakan produk jumlah responden yang memakai produk indosat kurang dari 1 tahun sebanyak 27 orang (22\%), 2 - 3 tahun sebanyak 47 orang (38\%), $4-6$ tahun sebanyak 33 orang (26\%), dan lebih dari 6 tahun sebanyak 18 orang (14\%). Dari pernyataan tersebut mayoritas responden telah menggunakan responden selama $2-3$ tahun.

Tabel 2. Deskripsi Karakteristik Responden

\begin{tabular}{|c|c|c|c|c|}
\hline No & \multicolumn{2}{|c|}{ Keterangan } & Jumlah & $\%$ \\
\hline \multirow{2}{*}{1} & \multirow{2}{*}{ Jenis Kelamin } & Wanita & 59 & 47 \\
\hline & & Pria & 66 & 53 \\
\hline \multirow{4}{*}{2} & \multirow{4}{*}{ Umur } & 17-20 Tahun & 41 & 33 \\
\hline & & 21-25 Tahun & 33 & 26 \\
\hline & & 26-30 Tahun & 30 & 24 \\
\hline & & $>30$ Tahun & 21 & 17 \\
\hline \multirow{6}{*}{2} & \multirow{6}{*}{ Pekerjaan } & Pelajar/mahasiswa & 43 & 34 \\
\hline & & Swasta & 36 & 29 \\
\hline & & PNS/ASN & 17 & 14 \\
\hline & & Wiraswasta & 10 & 8 \\
\hline & & Ibu Rumah Tangga & 15 & 12 \\
\hline & & Lain-lain & 4 & 3 \\
\hline \multirow{4}{*}{3} & \multirow{4}{*}{ Penghasilan } & $\leq 1.500 .000$ & 53 & 42 \\
\hline & & $1.500 .001-2.500 .000$ & 24 & 19 \\
\hline & & $2.500 .001-3.500 .00$ & 27 & 22 \\
\hline & & $>3.500 .000$ & 21 & 17 \\
\hline \multirow{4}{*}{4} & \multirow{4}{*}{$\begin{array}{l}\text { Lama Pakai } \\
\text { Produk Indosat }\end{array}$} & $\leq 1$ tahun & 27 & 22 \\
\hline & & 2 - 3 Tahun & 47 & 38 \\
\hline & & 4-6 Tahun & 33 & 26 \\
\hline & & $\geq 6$ tahun & 18 & 14 \\
\hline
\end{tabular}

Sumber: Data diolah, 2019

Tabel 3. Hasil Uji regresi Linear Berganda

\begin{tabular}{|l|r|c|c|}
\hline Variabel Independen & Nilai Beta & Sig & Ket \\
\hline Konstanta & 3.604 & & Berpengaruh \\
\hline Harga & 0.269 & 0.003 & Berpengaruh \\
\hline Kualitas & 0.164 & 0.024 & Berpengaruh \\
\hline Lokasi & 0.266 & 0.005 & Berpengaruh \\
\hline Pribadi & 0.313 & 0.002 & Tidak Berpengaruh \\
\hline Stimulus & 0.097 & 0.090 & 0.677 \\
\hline Nilai F & 20.146 & Nilai R & 0.436 \\
Sig. & 0,0000 & Adj. R Square &
\end{tabular}

*Konstanta: keputusan pembelian ulang

Sumber : Hasil olah data, 2019 
Hasil perhitungan analisi regresi berganda menunjukan bahwa variabel independen yang diproksi melalui Harga, Kualitas Layanan, Lokasi, Pribadi dan Stimulus terhadap variabel dependennya yaitu keputusan membeli ulang produk IM3 ooredoo menunjukan hasil yang dapat disusun model regresi linear berganda yaitu:

$$
\begin{aligned}
Y= & 3,604+0,269 \times 1+0,164 \times 2+0,266 \times 3 \\
& +0.313 x 4+0.097 \times 5
\end{aligned}
$$

Nilai konstansta yang menunjukan nilai 3,604 nyatakan bahwa variabel bebas (Harga, Kualitas Layanan, Lokasi, Pribadi dan Stimulus) adalah 0, maka besarnya pembelian ulang produk IM3 Ooredoo dinilai 3,604 satuan. Perolehan nilai beta masingmasing variabel bebas Harga, Kualitas Layanan, Lokasi, Pribadi dan Stimulus) yaitu positif, maka hubungan antara variabel dependen dan independen dapat dipastikan adalah searah.

Dari hasil uji regresi, diketahui secara parsial variabel harga memiliki nilai signifikan 0,003, kualitas dengan nilai signifikan 0,024, lokasi dengan perolehan nilai signifikan 0,005 dan pribadi dengan nilai signifikan 0,002. Dengan demikian keempat variabel tersebut dinilai mampu mempengaruhi variabel keputusan membeli ulang produk IM3 ooredoo, karena memiliki nilai dibawah level of significant $5 \%$. Sehingga hipotesis 1(satu) sampai ke 4 (empat) dinyatakan diterima

Sedangkan variabel stimulus dinilai tidak mempengaruhi variabel keputusan membeli ulang produk IM3 ooredoo karena memiliki nilai signifikan sebesar 0,090 atau di atas level of significant 5\%. Sehingga hipotesis ke 5 (lima) dinyatakan di tolak.

Hasil yang menyatakan bahwa pengaruh Harga, Kualitas Layanan, Lokasi, Pribadi dapat mempengaruhi keputusan pembelian ulang sejalan dengan beberapa penelitian sebelumnya. Dari perolehan nilai signifikan terendah, faktor pribadi merupakan faktor paling dominan, hal ini sejalan dengan penelitian Awi \& Chaipoopirutana (2014), Pupuani \& Sulistyawati (2013), serta Joseph, dkk (2012) dimana faktor pribadi dikaitkan dengan nilai yang dirasakan dirasakan (perceived value). Dan harga merupakan faktor selanjutnya yang dinilai signifikan dalam pempengaruhi keputusan membeli ulang. Keterjangkauan harga diringai dengan kualitas pelayanan yang diberikan umpan balik yang baik dalam membentuk opini dibenak konsumen (Putri, 2016) .

Faktor lokasi juga menjadi faktor yang dapat dipertimbangkan mengingat konsumen saat ini menuntut adanya kemudahan akses dalam mendapatkan segala kebutuhannya

Untuk pengujian secara simultan (uji F) diketahui nilai signifikan yang diperoleh adalah 0,000 atau di bawah level of significant 5\% sehingga hipotesis ke 6 (enam) yaitu Faktor Harga, Kualitas Layanan, Lokasi, Pribadi dan Stimulus Berpengaruh Secara Bersama-sama (Simultan) Terhadap Keputusan Membeli Ulang Produk Kuota IM3 Ooredoo Di Kota Banjarmasin dapat diterima.

Nilai Adjusted $R$ Square yang menunjukan angka 0,436 menunjukan bahwa model penelitian hanya mampu menjelaskan sebesar 43,6 \% bahwa pengaruh variabel Harga, Kualitas Layanan, Lokasi, Pribadi dan Stimulus terhadap Keputusan Membeli Ulang Produk Kuota IM3 Ooredoo Di Kota Banjarmasin. Sisanya yaitu $56,4 \%$ dapat dipengaruhi model lain selain variabel yang diuji.

\section{KESIMPULAN DAN SARAN}

\section{Kesimpulan}

Dari hasil uji regresi diketahui bahwa secara partial (sendiri-sendiri) variabel bebas yaitu Harga, Kualitas Layanan, Lokasi dan Pribadi mempu mempengaruhi Keputusan 
Membeli Ulang Produk Kuota IM3 Ooredoo Di Kota Banjarmasin. Sedangkan variabel stimulus tidak mampu mempengaruhi Keputusan Membeli Ulang Produk Kuota IM3 Ooredoo Di Kota Banjarmasin.

Secara bersama-sama (simultan) variabel Harga, Kualitas Layanan, Lokasi, Pribadi dan Stimulus mampu mempengaruhi Keputusan Membeli Ulang Produk Kuota IM3 Ooredoo Di Kota Banjarmasin.

\section{Saran}

Penelitian ini menemukan nilai R Square hanya sebesar $43.6 \%$ sehingga menyarankan kepada peneliti selanjutnya untuk dapat menambahkan variabel lain yang dapat memperkuat hubungan persepsi konsumen dengan keputusan membeli ulang.

\section{DAFTAR PUSTAKA}

Agus, Eko Sujianto. 2009. Aplikasi Statistik dengan SPSS 16.0. Jakarta: Prestasi Pustaka.

Awi, Y. L., \& Chaipoopirutana, S. 2014. A Study of Factors Affecting Consumer's RepurchaseIntention toward XYZ Restaurant in Myanmar. International Conference on Trends in Economics, Humanities, and Management .

Az. Nasution, 2014, Hukum Perlindungan Konsumen di Indonesia, Bandung: PT. Citra Adiya Bakti

Christoper Lovelock \& Lauren K Wright. 2007. Manajemen Pemasaran Jasa, PT. Indeks, Indonesia

Engel, J.,et al. 2006. Consumer Behaviour. Mason: Permissions Department, Thomson Business and Economics.

Ghozali, I. 2013. Aplikasi Analisis Multivariate dengan Program IBM SPSS 21 Update PLS Regresi I, Edisi Ketujuh, Semarang: Badan Penerbit Universitas Diponegoro

Hurriyati, Ratih. 2010. Bauran Pemasaran dan Loyalitas Konsumen. Bandung:

\section{ALFABETHA}

Huwaida, H. (2017). KOMUNIKASI PEMASARAN PADA PT ASURANSI ALLIANZ LIFE INDONESIA CABANG BANJARMASIN. At-Tadbir: jurnal ilmiah manajemen, 1(1), 13-27.

Kotler, Philip and Gary Armstrong. 2008. Prinsip-prinsip Pemasaran. Edisi. 12.

Jilid 1. Jakarta: Erlangga

Kotler, P., dan Keller, K. 2009. Manajemen Pemasaran, Edisi Ketigabelas, Jilid 1. Jakarta: Penerbit Erlangga.

Kotler, P., dan Keller, K. 2009. Manajemen Pemasaran, Edisi Ketigabelas, Jilid 2.

Jakarta: Penerbit Erlangga

Kusdyah, I. 2012. Persepsi Harga, Persepsi

Merk, Persepsi Nilai, dan Keinginan

Pembelian Ulang JasaClinic Kesehatan (Studi Kasus Erha Clinic Surabaya). 7. Peter, J.P., dan Olson, J.C. 2010. Consumer Behavior and Marketing Strategy. 9thEdition. New York, USA: Mc Graw Hill

Pupuani, N. W., \& Sulistyawati, E. (2013). Pengaruh Bauran Pemasaran Terhadap Kepuasan Konsumen Dan Perilaku Pembelian Ulang (Studi Kasus pada Produk Pasta Gigi Merek Pepsodent di Kota Denpasar). E-Jurnal Manajemen, 2(6).

Putri, Laurensia Hanjani,2016. Faktor-

Faktor yang mempengaruhi Minat

Pembelian ulang Konsumen Terhadap

Produk Naget Delicy. PERFORMA: Jurnal Manajemen dan Start-Up Bisnis Volume 1, Nomor 2.

Schiffman, Leon G.; Kanuk, Leslie Lazar. 2010. Consumer Behavior, 8th. New Jersey: Prentice Hall

Sekaran, U. dan Bougie, R. 2010. Research Methods for Business: A Skill Building Approach. $5^{\text {th }}$ Edition. West Sussex, United Kingdom: John Wiley \& Sons Ltd 
Stephen P.Robbins. 2009. Perilaku Organisasi. Jakarta: Salemba Empat

Sweeney J.C, dan Wyber F. 2002. The Role of Cognitions and Emotions in the Music -Approach-Avoidance Behavior Relationship. Journal Service Marketing,16 (1), hal. 51-69
Tjiptono, Fandy. 2011. Strategi Pemasaran. Edisi 3. Yogyakarta : ANDI 